\title{
The Development of the Values Education in Vocational High School in Indonesia
}

\author{
Puji Iswanto, C. Rudy Prihantoro, Ratu Amilia Avianti \\ Department of Mechanical Engineering, Faculty of Engineering, Universitas Negeri Jakarta, Jakarta, Indonesia \\ Email address: \\ pujiiswanto10@gmail.com (P. Iswanto),crudy@unj.ac.id (C. R. Prihantoro), avianti.raa@gmail.com (R. A. Avianti)
}

\section{To cite this article:}

Puji Iswanto, C. Rudy Prihantoro, Ratu Amilia Avianti. The Development of the Values Education in Vocational High School in Indonesia. International Journal of Vocational Education and Training Research. Vol. 1, No. 1, 2015, pp. 1-4. doi: 10.11648/j.ijvetr.20150101.11

\begin{abstract}
Writing this paper aims to discuss the values of vocational education the right was developed in vocational high school. So that vocational high school have character innovative, creative, productive, competitively, and grow a sustainable future front as well as the principles, policies, strategies and challenges development of the values education in vocational high schools. Development of the value education in vocational high schools are required to build professional values education continuing vocational future. The value education of vocational build independence rational learners to find maximum benefit, the vocational high schools can learn from global values to develop local values and support the development of locally in the context of globalization. In doing uptake of global value, vocational high schools are advised to use the three theories, namely: (1) the theory of trees, (2) the theory of crystal, (3) the theory of the bird cage.
\end{abstract}

Keywords: Development, Education, Vocational High School, Values Education

\section{Introduction}

Civilizing values in shaping vocational high schools character innovative, creative, competitive and sustainable require sociocultural and structural support. Global transformation towards knowledge-based economy, encouraging an increase in demand for quality human development as a resource, international and regional competitions in various parts of the world (Cheng, 2005). In a community-based industry knowledge has been an increased openness, flexibility, complexity, and uncertainty (Tessa ring, 2009; Heinz, 2009; Billet, 2009; Wagner, 2008). So that vocational high schools need education with new values relevant with the needs of the individual, local, national, regional, and global character.

In sociocultural patterns of civilizing values vocational in the vocational high school expected to meet the requirements for:

1. Develop cognitive skills and psychomotor individual learners (Emmerik, Bekker, \& Euwema, 2009; Kellet, Humphrey, \& Sleeth, 2009)

2. Develop the attitude (Stumpf, 2009)

3. Develop a positive appreciation of the work, building a work culture (Heinz, 2009), building a learning culture, innovative culture, creative and productive (Thompson, 1973; Gill, Dar, and Fluitman, 2000)
4. Prepare learners for work, entrepreneurship, or forward (Wardiman, 1998)

5. Empower learners to get a job and income decent (Gill, Dar, and Fluitman, 2000)

6. Develop a career in accordance with selected competency skills (Kellet, Humphrey, Sleeth, 2009)

7. Facilitate the fulfillment of all the needs of learners of both physical and non physical, moral, and also future needs to live comfortably, safely and happy in society (Rojewski, 2009)

8. Involving community stakeholders interests broadly, intact, right, and responsibility (S. McGrath, 2009)

Structurally vocational high school is schooling system is designed and organized by the government, instead of education held by the business community and industrial world (Smith Supriya, 2002) so that require familiarization pattern vocational values with the specific context of Indonesia (Herschbach, 2009). This paper discusses vocational values such as whether the right was developed in vocational high schools. So that vocational high schools have character innovative, creative, productive, competitively, and sustainable growth in the future and how the principles, strategies and challenges of development the value education in vocational high schools. 


\section{Values of Vocational Education in Vocational High Schools}

According Rojewski (2009) the development of technology and vocational education requires a conceptual framework are evident in meet objectives effectively, efficiently, and meaningful. Conceptual framework pattern civilizing vocational values in vocational high school in each of the different regions of the each other because each region in Indonesia has a sociocultural characteristics unique, the potential of different regions, different local advantages, policy political and economic differently. Vocational education in vocational high schools have strategic value in terms of:

- Development of human resources education regional vocational (Herschbach, 2009)

- The development, structuring, preservation the potential of the area

- Strengthening local excellence insight

- An increase in insight into the future

- Strengthening quality insigh

- increase in value insight added

- professional development

- the fulfillment of service vocational education for the user voter education in vocational high schools.

Restructuring and rekulturisasi civilizing patterns vocational future values are expected to educate a person not just as workers (Hollander \& Mar, 2009), but a vocational education with holistic approach to accommodate all the needs of learners both physical or non-physical, moral, and also the future requirements for a comfortable life, safe and happy in the community (Rojewski, 2009). According to Dewey that the principal purpose of public education is to bring individual needs of learners for personal selffulfillment and preparation face and live (Rojewski, 2009). Pattern civilizing values of vocational expected is a pattern that is able to internalize local advantages, the potential region between national needs and challenges global.

\section{Civilizing Values of Vocational}

Pattern civilizing values of vocational expected to sit meaning importance of vocational education, vocational education functions, educational purposes, the benefits of vocational education, vocational education characteristics, principles vocational education, vocational education and grounding into the conception development of vocational education in vocational high schools. Pattern civilizing values of vocational in vocational hihg schools must be born and grow from the local community and culture become an integral part of the overall culture of the people.

Pragmatically vocational education in the 21 st century are required to build studying human intelligence, economic intelligence, social intelligence, cultural intelligence, technology intelligence, and also political intelligence (Cheng, 2005). Vocational education will be successful if it is able to develop human existence popularize vocational education, cultural competence in the order of dimensionless local, national, regional, and global. As a product of society, vocational education can not be separated from the community where vocational education is developed. Vocational education grew from society, grow with local culture, attention local advantages, potential region, community support, participation and cooperation society, there is a strong consensus among the people with institutions vocational education. Vision of vocational education should be congruent with the vision communities where vocational education developed (Tilaar, 1999).

\section{Education Value in Vocational High Schools}

In building the focus of vocational education values Aspin (2007) stated that vocational high schools must provide access and opportunities for learners to practice and apply the kind of knowledge, competencies, and attitudes in the process of preparing them for life in today's complex society. Schools should have a concern and promote vocational education values, excellence and high standards as individual and institutional aspirations, achievement and conduct in all aspects of its work. Schools should be humane and give ample opportunity for learners to get the values that will be very important in personal and social development. Schools must develop a sense of independence and self-learners as human beings, have the confidence to contribute to the community, to be part of the society within the framework of social and political life of a civilized and moral.

Furthermore, schools should prepare for future students as community members and citizens to do the interpersonal relationships of the each other, in a way that does not conflict with the health and stability community or individual. Schools must prepare students to have concern for the vitality of cultural values, as well as economic enrichment in communities in which they will eventually play a role, promoting himself and enjoy the artistic and expressive experience in addition to the acquisition of knowledge and work. Schools must incorporate education for personal autonomy rational, community development and social contribute to happiness, prosperity, and peace so that each learner can enrich community where he became part of the community, as grantor, leader and innovators, as well as an heir and a recipient of high culture.

From the foregoing description it can be concluded that vocational high schools must seek and find an approach to build and offer a curriculum, teaching and learning activities will concentrate not only on vocational competence, economic capacity and management skills but also on human values. For that all the community in vocational high schools need to:

1. Understand and appreciate the community's history, cultural heritage and traditions of the community

2. Develop tolerance and sympathy for having and willingness to work and live with other people from 
different backgrounds, interests and lifestyles

3. Develop a sense of respect for others, considering their interests and sensitive to interpersonal relations, communication and menjada courtesy

4. Take part in arts and cultural activities, and the opportunity they offer to the imagination and creativity

5. Appreciate the importance of ethics in business, work, perform the creation, exercise and personal relationships

6 . Independent and rational

7. Receives the search for meaning that is offered by religion, culture, customs, humanism, and more appreciated as a way of living together

\section{Challenges and Strategies for the Development of the Values Education in Vocational High Schools}

In order open global industrial society, full competition, and changing rapidly due to the influence of information technology and communications, the development of the value education in vocational high schools will be faced to the problems of structuring influence individualization context, localization, and globalization (Pascoe, 2007; Cheng 2005). Development of the value education of vocational industrial character in vocational high schools need to pay attention to aspects of intelligence technology, economic, social, political, and cultural environment as a basic perspective.

According to Cheng (2000), in the new millennium there are some globalization namely: the globalization of technology, economic globalization, social globalization, globalization political, cultural globalization, and globalization of learning. How should education responsive to trends and challenges of globalization has become a major concern policy in the years (Cheng, 2005). Globalization refers to the transfer, adaptation, and development of values, knowledge, technology, and norms behavior across countries and communities in various parts of the world. Phenomenon typical and characteristics associated with globalization including growth global network, for example the internet, the world wide ecommunication, and transportation, global transfer and united in technology, economic alliances, social, political, cultural, competition, international cooperation and student exchange, global village, integration multi-cultural, and the use of international standards.

Localization refers to the transfer, adaptation, and development of related values, knowledge, technology, and norms of behavior from / to the local context. The implications of the localization of the value of education is to maximize the relevance of educational value for regional development and bring the community support and resources, local partnerships, and collaboration in learning, teaching, and school. Individualization refers to the transfer, adaptation, and development of related external values, knowledge, technology, and norms of behavior to meet individual needs.
Although globalization is creating many opportunities to share knowledge, technology, social values, and norms of behavior that promotes the development of individuals, organizations, and communities, local values still have to be a filter base. Creation of value that can improve efficiency and productivity through global influence and support each other to serve the needs of local and human development needs to be sought and cultivated.

Values local knowledge is knowledge that has been tested applicable in the local context and an accumulation of local communities. In order to find the maximum benefit, the vocational high schools can learn from global values to develop local values and support local development in the context of globalization. In doing uptake suggested using the global value three theories, namely:

1. The theory of trees

2. The theory of crystal

3. The theory of the bird cage.

The theory assumes tree as tree growth. The process of formation of local knowledge should rooted in local values and local traditions but absorb useful and relevant resources from external systems or knowledge and global values to grow throughout the local values into the system knowledge. Therefore, developing local values through global education needs of local identity and local culture rooted require curriculum design based on local values and local cultural assets but absorbs a suitable global knowledge and technology to support the development of local communities and individu- individuals as nationals. Theory crystals cling to the key of the coaching process, namely its local seeds to crystallize and accumulate global knowledge. Guidance values are directed to accumulate global knowledge around some local seed. Theory birdhouse found functions like a bird cage, the process of coaching knowledge and local values can be open to knowledge and global value entered but no attempt should be made to restrict or converging local development and interaction with the outside world within the framework of fixed, ie in the bird cage. This means that the development of local knowledge in global education requires local frameworks, such as a bird cage for filtering incoming external knowledge and protecting the local development of a global negative influence.

\section{Conclusion}

Values education in vocational high schools is indispensable in order to develop human existence popularize vocational education, cultural competence in the livelihood of the local dimension, national, regional, and global. In order to improve the bargaining position, the vocational high school in the future should look for and find an approach to build and offer a curriculum, teaching and learning activities that focus not only on vocational competence, economic capacity and management skills but also on human values. Values local knowledge is knowledge that has been tested applicable in the local context and an accumulation of local communities. To find the maximum benefits the local 
community can learn from global values to develop local values and support local development in the context of globalization. In doing uptake global value suggested using three theories, namely:

1. The theory of tree

2. The theory of crystal

3. The theory of the bird cage

\section{Suggestion}

Value education very beneficial for the development of vocational high schools in the global era. Therefore, the government should prioritize this for the future progress of secondary vocational schools. Not only the government, the public should also help for the sake of national education quality.

\section{References}

[1] Aspin, D.N., (2007). The Ontology of Values and Values Educatio;in Aspin D.N \& Chapman J.D.; Values Education And Lifelong Learning Principles, Policies, and Programs:Netherlans: Springer.

[2] Billet S.,(2009), Changing Work, Work Practice: The Consequences for Vocational Education; in Rupert Maclean, David Wilson, Chris Chinien; International Handbook of Education for the Changing World of Work, Bridging Academic and Vocational Learning: Germany: Springer Science+Business Media.

[3] Cheng, Y.C. (2005). New Paradigm for Re-engineering Education, Globalization, Localization and Individualization. Netherland: Springer.

[4] Emmerik I.J. H. V., Bakker A.B, Euwema M.C.. (2009). Explaining employees' evaluations of organizational change with the job-demands resources model; Career Development International Journal Vol. 14 No. 6, 2009 pp. 594-613

[5] Gill,I.S.,Fluitman.F.,\& Dar.A. (2000). Vocational Education and Training Reform, Matching Skills to Markets and Budgets.Washington: Oxford University Press.

[6] Heinz .W.R (2009). Redefining the Status of Occupations; in Rupert Maclean, David Wilson, Chris Chinien; International Handbook of Education for the Changing World of Work, Bridging Academic and Vocational Learning: Germany: Springer Science+Business Media.

[7] Herschbach D.R. (2009) Overview: Navigating the Policy Landscape: Education, Training and Work, 869-890: Rupert Maclean, David Wilson, Chris Chinien; International Handbook of Education for the Changing World of Work, Bridging Academic and Vocational Learning: Germany: Springer Science+Business Media.
[8] Hiniker L.A. and Putnam,R.A. (2009). Partnering to Meet the Needs of a Changing Workplace; in Rupert Maclean, David Wilson, Chris Chinien; International Handbook of Education for the Changing World of Work, Bridging Academic and Vocational Learning: Germany: Springer Science+Business Media.

[9] Hollander A. \& Mar N.Y (2009) Towards Achieving TVET for All: The Roleof the UNESCOUNEVOC International Centre for Tehenical and Vocational Education and Training, 41-57: in Rupert Maclean, David Wilson, Chris Chinien; International Handbook of Education for the Changing World of Work, Bridging Academic and Vocational Learning: Germany: Springer Science+Business Media.

[10] Kellett J.B, Humphrey R.H. and Sleeth R.G.(2009) Career development, collective efficacy, and individual task performance, Career Development International Vol. 14 No. 6, 2009 pp. 534-546 q Emerald Group Publishing Limited 13620436 .

[11] McGrath S. (2009) Reforming Skills Development, Transforming the Nation: South African Vocational Education and Training Reforms, 1994-2005: Rupert Maclean, David Wilson, Chris Chinien; International Handbook of Education for the Changing World of Work, Bridging Academic and Vocational Learning: Germany: Springer Science+Business Media.

[12] Rojewski. J.W (2009). A Conceptual Framework for Technical and Vocational Education and Training; in Rupert Maclean, David Wilson, Chris Chinien; International Handbook of Education for the Changing World of Work, Bridging Academic and Vocational Learning: Germany: Springer Science+Business Media.

[13] Stumpf. S.A (2009). Promotion to partnerThe importance of relationship competencies and interpersonal style. Career Development International Vol. 14 No. 5, 2009 pp. 428-440 q Emerald Group Publishing Limited 1362-0436.

[14] Tessaring M.,(2009). Anticipation of Skill Requierements: European Activities and Approaches; In Rupert Maclean, David Wilson, Chris Chinien; International Handbook of Education for the Changing World of Work, Bridging Academic and Vocational Learning: Germany: Springer Science+Business Media.

[15] Thompson, John F, (1973). Foundation of Vocational Education Social and Philosophical Concepts. Prentice-Hall: New Jersey

[16] Tilaar, H.A.R., (2002). Perubahan Sosial dan Pendidikan, Pengantar Pedagogik Transformatif untuk Indonesia. Jakarta: PT. Gramedia.

[17] Wagner T. (2008). The Global Achievement Gap. New York: Basic Books. 